\title{
Exogenous induction of ovarian activity and ovulation and transfer of fresh embryos of domestic cat (Felis catus) ${ }^{1}$
}

\author{
Marcelo Lopes Santana², Tarcízio Antônio Rego de Paula ${ }^{3}$ Eduardo Paulino da Costa ${ }^{4}$, Deiler Sampaio Costa
}

\begin{abstract}
The objective of the present study was the exogenous stimulation of ovarian activity and definition of embryo collection, and transfer protocols, in the domestic cat for potential application in non-domestic endangered species. Sixteen adult queens and two adult male reproducers kept in the experimental cat house at the Morphology sector at the Veterinary Department (DVT), UFV, were used in this study. All the queens received a single application of 150 IU Equine Chorionic Gonadotropin (eCG) in the post estrus to induce ovarian activity and 80 to 84 hours later, received a single application of 100 UI Human Chorionic Gonadotropin (hCG) to induce ovulation. After hCG application, only the donor queens were naturally mated. The receptor queens received extra stimulus for induction of ovulation through manipulation of an intravaginal swab. Five to six days after hCG application, the donor queens were subjected to a laparotomy for embryo collection that was performed by trans-horn uterine washing. On average, six embryos were surgically inovulated. They were classified as type I and III compact morula and blastocysts in four receptor queens. Three animals presented pregnancy confirmed by ultrasound at day 36 and two of these animals gave birth to litters of two and four offsprings, respectively, at 66 and 63 days after induction of ovulation. Except for one still birth, all the offspring developed normally.
\end{abstract}

Key words: ovarian activity induction, ovulation, embryo transfer, domestic cat.

\section{ABSTRACT \\ Indução exógena da atividade ovariana e da ovulação e transferência de embriões a fresco em gatas domésticas (Felis catus)}

Os objetivos deste trabalho foram avaliar a estimulação exógena da atividade do ovário e a definição de protocolos para recolhimento e transferência de embriões em gatos domésticos, para aplicação potencial em espécies selvagens ameaçadas de extinção. Foram utilizados 16 gatas domésticas adultas e dois machos adultos reprodutores, mantidos no gatil experimental do setor de Morfologia do DVT-UFV. Todas as fêmeas receberam uma única aplicação de 150 UI de Gonadotrofina Coriônica Equina (eCG) no pós-estro, como indutor da atividade ovariana e, 80 a 84 horas após, receberam uma única aplicação de 100 UI de Gonadotrofina Coriônica Humana (hCG), como indutor da ovulação. Após a aplicação de hCG, apenas as gatas doadoras foram naturalmente acasaladas. As gatas receptoras receberam estímulo extra de indução da ovulação por meio da manipulação de um swab intravaginal. Cinco a seis dias após a aplicação de hCG, as gatas doadoras foram submetidas a uma laparotomia, para a coleta dos embriões, a qual foi efetuada mediante

Received for publication on March $23^{\text {th }}, 2010$ and approved on July $06^{\text {th }}, 2012$.

${ }^{1}$ Extracted from the first author' Post-Graduation dissertation in Veterinary Medicine-UFV

2 Veterinary, Master of Science. Departamento de Veterinária, Universidade Federal de Viçosa, Campus Viçosa, Avenida Peter Henry Rolfs, s/n, 36570-000, Viçosa, Minas Gerais, Brazil.mssantana@yahoo.com.br

${ }^{3}$ Veterinarian, Doctor Science. Departamento de Veterinária, Universidade Federal de Viçosa, Campus Viçosa, Avenida Peter Henry Rolfs, s/n, 36570-000, Viçosa, Minas Gerais, Brazil.tarcizio@ufv.br (autor correspondente).

${ }^{4}$ Veterinarian, Doctor Science. Departamento de Veterinária, Universidade Federal de Viçosa, Campus Viçosa, Avenida Peter Henry Rolfs, s/n, 36570-000, Viçosa, Minas Gerais, Brazil. epcosta@ufv.br

${ }_{5}^{5}$ Veterinarians, Doctor Science. Faculdade de Medicina Veterinária e Zootecnia, Universidade Federal de Mato Grosso do Sul, Cidade Universitária, 79070-900, Campo Grande, Mato Grosso do Sul, Brazil. deilercosta@ufms.br 
lavagem uterina transcornual. Foram cirurgicamente inovulados, em média, seis embriões, classificados como mórula compacta e blastocisto dos tipos I a III, em quatro receptoras. Três animais apresentaram gestação confirmada por ultrassonografia aos 36 dias, sendo que dois animais pariram ninhadas com dois e quatro filhotes, respectivamente, 66 e 63 dias após a indução da ovulação. Excetuando-se um natimorto, todos os filhotes apresentaram desenvolvimento normal.

Palavras-chave: indução da atividade ovariana, ovulação, transferência de embriões, gata doméstica.

\section{INTRODUCTION}

The increasing degradation of the environment, caused by deforestation, dam constructions, environmental accidents such as chemical product spills and fires, has as a direct consequence the reduction and fragmentation of many ecosystems, causing many species to suffer a sharp decline in their numbers and consequent loss of genetic diversity (Guimarães, 2002). The continuous pressure from illegal hunting and progressive decrease in the habitats have led, according to the criteria by Mace and Lande (1991), Tewes \& Everett (1986) and Tewes \& Schmidly (1987) to the inclusion of all the Brazilian wildcat species into endangered condition. Dominion over the repeatability and adaptation of assisted reproduction protocols in the domestic cat is very valuable for development and adaptation for wild species, and it may play an important role in the conservation of endangered species in the near future. Thus, the domestic cat has been used intensively as an experimental model for different techniques, including: in vitro embryo maturation and fertilization (Bowen, 1977; Donoghue et al., 1992; Byers et al., 1992; Roth et al., 1994; Johnston et al., 1996; Karja et al., 2002), embryogenesis and embryo migration (Swanson et al., 1994), in vitro embryo development (Goodrowe et al. 1988; Kanda et al., 1995; Pope et al., 1998; Skrzyszowska et al., 2002; Gómez et al., 2003), artificial ovulation induction (Greulich, 1934; Tsutsui et al., 1989), culture (Jewgenow et al., 1995; Murakami et al., 2002), transfer (Platz et al., 1978; Goodrowe et al., 1988; Wood et al., 1995; Pope, 2000; Tsutsui et al., 2000; Kitiyanant et al., 2003) and embryo cryopreservation (Ballou, 1992; Leibo \& Songsasen, 2002).

The domestic cat is classically defined as a seasonal polyestrus species in geographic regions with marked climatic seasons (Jemmett \& Evans, 1977; Pope, 2000; Johnston et al., 1996). These animals' cycle throughout the year under Brazilian climatic conditions, although presenting an increase in the interestrus phase in the fall and the winter, does not present seasonal anestrus (Ávila et al., 2003).

Rev. Ceres, Viçosa, v. 59, n.4, p. 499-505, jul/ago, 2012
The estrus cycle of the female cat may include the phases of proestrus, estrus, post estrus, diestrus and anestrus. When the proestrus occurs, it can last up to two days, the females then attract the males for mating but are not yet receptive (Johnston et al., 2001). The estrus is easily detected and lasts an average of five to seven days. During this phase, the female will accept a male (Shille et al., 1979; Christiansen, 1988; Pope, 2000). These animals are reflex ovulators; that is, the ovulation only occurs after coitus, which induces the release of the Gonadotroprin Hormone Releaser (GnRH) that in turn leads to a serum increase in Luteinizing Hormone, culminating in the ovulation (Goodrowe et al., 1989; Johnson \& Gay, 1981; Wildt et al., 1980), which occurs 24 to 50 hours after the coitus (Christiansen, 1988). Physiologically, about three to four primordial follicles of 1 to $2 \mathrm{~mm}$ in diameter develop in the queen during the post estrus phase (Christiansen, 1988; Goodrowe et al. 1989).

If coitus does not take place, the queen is not induced to ovulate, and follicular regression occurs. Then, a period called post estrus, from eight to 10 days, is established. Queens that fail to conceive present a phase of luteal persistance of approximately 40 days, also called pseudopregnancy (Verhage et al., 1976; Goodrowe et al., 1989; Johnston et al., 2001). In pregnant animals, the luteal phase lasts until birth, for approximately 60 days (Johnston et al., 2001). According to Johnston et al. (1996), the size of the litter ranges from one to five offsprings with an average of 3.7 per birth, and there is no relationship between the offspring number and pregnancy duration.

Equine chorionic gonadotropin (eCG) or the follicle stimulating hormone (FSH) can be used to induce ovarian activity and human chorionic gonadotropin ( $\mathrm{hCG}$ ) can be used to induce ovulation in felids (Howard et al., 1992; Platz, et al. 1978; Pope et al., 1993; Pope et al., 1998). The results obtained from this induction are similar to those observed in natural reproduction (Cline, et al., 1980). In order to collect embryos, treatment with gonadotropins should be started preferably in the post estrus stage, which can be determined by the absence of estrus behavior or accompanied by vaginal cytology. The best results have 
been obtained using 100 IU hCG 80 - 84 hours after the eCG application (Pope et al., 1998; Donoghue et al., 1992; Goodrowe et al., 1988).

According to Swanson et al. (1995), gonadotropin used at very short intervals to induce ovarian activity stimulates the synthesis of immunoglobin, which in turn neutralizes the effect of the gonadotropins. In felid assisted reproduction programs, the success of the artificial insemination process depends on the deposit site of semen, and low pregnancy rates have been observed with intravaginal deposit (Platz et al., 1978). Anaesthetized animals have shown impairment in the transport of sperm and ovulation (Howard, 1998; Howard et al. 1992). Because induced ovulation occurs about 25 to 27 hours after hCG injection and the oocyte viability is at least 14 hours in vivo, the best results for intrauterine insemination occur about 36 hours after induction of hormonal ovulation (Howard et al. 1992; Donoghue et al. 1996; Howard, 1998).

After fertilization, most of the embryos remain in the uterine tube for the first 136 hours, that is, the embryos enter the uterus as compact morula or initial blastocysts starting 5.5 days after ovulation, making transuterine migrations before their implantation (Swanson et al., 1994). Embryo implantation begins 13 days post mate, after hatching from the pelucide zone on day 12 (Dresser et al., 1988).

Embryo recovery and their intra- and interspecific transfer had been reported in felids (Kraemer et al., 1979; Bowen et al., 1982; Pope et al., 1993; Pope, 2000). Recovery in the domestic cat should be made between 6 and 9 days after mating (Kraemer et al.,1979). Swanson \& Godke (1994) proposed a less invasive transcervical technique for embryo recovery and transfer, but the most-used technique is surgery (Kraemer et al., 1979; Dresser et al., 1988; Kanda et al., 1995; Pope, 2000; Tsutsui et al., 2000).

Most studies reported in the literature on domestic cat assisted reproduction have been carried out under climatic conditions that are different from the Brazilian conditions. Thus, because domestic cat reproduction is seasonally influenced by climatic oscillations, mainly the photoperiod, the objective of the present study was the adaptation to the Brazilian climatic conditions of exogenous ovarian activity and ovulation induction as well as embryo collection protocols, classification and transfer in the domestic cat for potential application in non-domestic endangered species.

\section{MATERIALS AND METHODS}

Sixteen domestic queens were used in the experiment: eight with characteristics of the Siamese breed and eight without defined breed characteristics (SRD). They were kept in a colony in the experimental cathouse at the morphology sector of the Veterinary Department (DVT), $\mathrm{UFV}$, with an area of $24 \mathrm{~m}^{2}$, including a $12 \mathrm{~m}^{2}$ solarium. Two adult male reproducers also with characteristics of the Siamese breed were included in the study. They were kept in individual pens with a covered area of $2 \mathrm{~m}^{2}$ and a $0.5 \mathrm{~m}^{2}$ solarium inside the same cathouse. All the females were monitored by vaginal swabbing to detect the postestrus period, when the protocol for the induction of the ovarian activity began.

Four embryo collections and transfer procedures were carried out. In each procedure, two queens with the Siamese breed characteristics were used as donors and two queens without defined breed characteristics as receptors. In each procedure, all the females received a single intramuscular application of $150 \mathrm{IU}$ eCG to induce ovarian activity. About 80 and 84 hours after the eCG application, 100 IU human chorionic gonadotropin (hCG) were also applied for induction of ovulation. Immediately after the hCG application, only the donor queens were mated with the male reproducer. The males were changed every 24 hours, for a total period of 72 hours, to ensure a greater number of matings and to reduce the possibility of individual failure by the male. The receptor queens received extra stimulation for induction of ovarian activity through the manipulation of an intravaginal swab, in circular movements, twice every 24 hours for 72 hours. After this time, the donors returned to community living in the cathouse.

Five to six days after the hCG application, all the queens were subjected to a pre-retroumbilical laparotomy incision within the linea alba to collect the embryos. The animals were anesthetized using the association of tiletaminazolazepam (Zoletil ${ }^{\circledR}$ ). In each animal, the number of hemorrhagic bodies and ovulation follicles on each ovary were counted. A trans-horn uterine washing technique was developed to collect the embryos. The technique consisted of the simultaneous exposure of the tube extremities of each uterine horn. They were stabilized by using hemostatic pincers on the ovary ligament, and the horns were catheterized by $18 \mathrm{~g}$ caliber venous catheters. Syringes were attached to the catheters and only one of them was filled with a known volume of the culture medium for embryo collection (Talp Herps). A continuous flow was produced by injecting the culture medium into one uterine horn and simultaneous aspiration from the other, promoting both washing of the uterine horn and embryo collection. This procedure was repeated two to three times. The uterine washings were placed on a sterile Petri dish and observed under a stereoscopic microscope to record quantitatively and qualitatively the embryos and other structures that were collected. The embryos were classified morphologically according to the procedure known as Robertson \& Nelson (1998). Only embryos 
classified as quality I, II and III were transferred. On the average, six embryos were placed between columns of air inside a rigid Tomcat catheter (no. 7), and inovulated at the cranial extremity of the horn with the greatest number of luteal bodies in each receptor queen. The pregnancy was monitored by ultrasound examinations at every 15 days.

\section{RESULTS AND DISCUSSION}

\section{Results}

In the present experiment, the dose of $100 \mathrm{IU}$ hCG applied $4 \mathrm{~h}$ after pre-stimulation with $150 \mathrm{IU}$ eCG was effective in promoting ovulation in all the females, and an average of 13.5 and 20 luteal bodies were recorded for the donor and receptor animals, respectively (Table 1 and 2). Table 1 shows the number of embryos and oocytes recovered from each donor animal. On average, about seven non-ovulated follicles were observed in each animal at the time of the laparotomy (Table 1 and 2). The recovery rate in these animals was $66 \%$. Table 1 also shows that, except for donor no. 6, which presented hydrossalpinge at the time of surgery, few degenerated embryos were recovered. Of the 42 non-degenerated embryos recovered from all the donors, $69 \%$ were classified as excellent quality compact morula (type I), 12 were good quality compact morula (type II), $12 \%$ were regular quality compact morula (type III), 9.5\% were excellent quality initial blastocysts and $4.8 \%$ were good-quality initial blastocysts (Table 1).

Only four of the eight animals selected as embryo receptors were used in the study (receptors 02, 03, 06 and 08), one in each procedure. That was because one of the females had pyometritis at the time of surgery, and another had malformation of the genital tract; and the two remaining queens were not used because there weren't enough embryos for the procedure. Table 2 shows that about 6 embryos were inovulated into each receptor, most compact morula type I.

Receptor no. 2 received eight embryos, three MCI, three MCIII and two BLII; it had a 66-day pregnancy with normal birth of two healthy offsprings. Receptor no. 3 received three MCI and two MCII embryos; it had a 63day pregnancy with normal birth of four offsprings, one of which was stillborn with cephalic malformation and three healthy offsprings. Receptor no. 6 received six MCI embryos but did not show any sign of pregnancy. Receptor no. 8 received five embryos, three MCI, one MCIII and one BLI; it presented embryonic vesicules in the first ultrasound exams that were not detected after 45 days of pregnancy. All the offsprings had characteristics of the Siamese breed, following the phenotypic pattern presented by the biological parents. They developed normally and were weaned at 60 days of age.

\section{Discussion}

Several protocols have been published in the literature for induction of ovarian activity, including the use of equine chorionic gonadotropin (eCG), pregnant mare serum gonadotropin (PMSG) or hypofisary follicle stimulating hormone (FSH-p), (Wildt et al ., 1978; Platz, et al. 1978; Dresser et al., 1988; Howard et al., 1992; Pope et al., 1993; Kanda et al., 1995; Pope et al., 1998; Tsutsui et al., 2000; Mattos et al ., 2003). According to Wildt et al. (1978), although being efficient in stimulating ovarian activity, FSH presents a short half-life, requiring various daily applications that can cause hyperstimulation. The use of eCG, at doses of 50 and $150 \mathrm{IU}$, had extremely satisfactory results with a single dose (Pope et al., 1998; Donoghue et al., 1992; Goodrowe et al., 1988; Tsutsui et al., 2000 ). In our study, the use of $150 \mathrm{IU}$ eCG was effective in inducing follicular development in all animals tested.

Table 1. Classification and quantification of the embryos and number of luteal bodies, ovarian follicles and oocytes in donor queens

\begin{tabular}{|c|c|c|c|c|c|c|c|c|c|c|c|}
\hline \multirow{2}{*}{ Date } & \multirow{2}{*}{ Donor } & \multirow{2}{*}{$* \mathbf{L B}$} & \multirow{2}{*}{$\begin{array}{l}\text { Ovarian } \\
\text { Folicucle }\end{array}$} & \multirow{2}{*}{$\begin{array}{l}\text { Colected } \\
\text { Embryos } \\
\text { Number }\end{array}$} & \multirow{2}{*}{ Oocytes } & \multicolumn{6}{|c|}{ Embrionary classification } \\
\hline & & & & & & $* * \mathbf{C M I}$ & CMII & CMIII & $* * * \mathbf{B L I}$ & BLII & $* * * *$ Deg. \\
\hline $04 / 23$ & 01 & 17 & 01 & 02 & - & - & - & - & - & - & 02 \\
\hline $04 / 23$ & 02 & 19 & 16 & 16 & - & 08 & - & 03 & 03 & 02 & - \\
\hline $05 / 21$ & 03 & 17 & 01 & 06 & - & 03 & 02 & - & - & - & 01 \\
\hline $05 / 21$ & 04 & 19 & 06 & 00 & 12 & - & - & - & - & - & - \\
\hline $09 / 30$ & 05 & 09 & 06 & 13 & - & 12 & - & 1 & - & - & - \\
\hline $09 / 30$ & 06 & 12 & 09 & 15 & - & 03 & - & - & - & - & 12 \\
\hline $11 / 04$ & 07 & 06 & 07 & 04 & - & 03 & - & 01 & - & - & - \\
\hline $11 / 04$ & 08 & 09 & 09 & 02 & 01 & - & - & - & 01 & - & 01 \\
\hline \multicolumn{2}{|c|}{ Total Number 08} & 108 & 55 & 58 & 13 & 29 & 02 & 05 & 04 & 02 & 16 \\
\hline Average & 1.0 & 13.5 & 6.88 & 7.25 & 1.63 & 3.63 & 0.25 & 0.63 & 0.5 & 0.25 & 2.00 \\
\hline
\end{tabular}

Rev. Ceres, Viçosa, v. 59, n.4, p. 499-505, jul/ago, 2012 
Table 2. Classification and quantification of transferred embryos. Number of luteal bodies and ovulation follicles in receptor queens

\begin{tabular}{lccccccccc}
\hline \multicolumn{1}{c}{ Date } & Receptor & $\begin{array}{c}\text { Luetal } \\
\text { bodies }\end{array}$ & $\begin{array}{c}\text { Ovulation } \\
\text { follicles }\end{array}$ & $\begin{array}{c}\text { Number of } \\
\text { transfered } \\
\text { embryos }\end{array}$ & *CMI & CMII & CMIII & **BL 1 & BL 2 \\
\hline $04 / 23$ & 01 & 23 & 09 & - & - & - & - & - & - \\
$04 / 23$ & 02 & 17 & 01 & 08 & 03 & - & 03 & - & 02 \\
$05 / 21$ & 03 & 16 & 06 & 05 & 03 & 02 & - & - & - \\
$05 / 21$ & 04 & $\mathrm{n}$ & $\mathrm{n}$ & - & - & - & - & - & - \\
$09 / 30$ & 05 & $\mathrm{n}$ & $\mathrm{n}$ & - & & & & - & - \\
$09 / 30$ & 06 & 20 & 08 & 06 & 06 & - & - & & - \\
$11 / 04$ & 07 & $\mathrm{n}$ & $\mathrm{n}$ & - & & & & & \\
$11 / 04$ & 08 & 24 & 15 & 05 & 03 & - & 01 & 01 & - \\
Total Number & 8.0 & 100.0 & 39.0 & 24.0 & 15.0 & 2.0 & 4.0 & 1.0 & 2.0 \\
Average & 1.0 & 20.0 & 7.88 & 6.00 & 3.75 & 0.5 & 1.0 & $0 . .25$ & 0.5 \\
\hline
\end{tabular}

* LB: Number of luteal bodies; ** CMI, II and III: Compact morules type I, II and III; *** BL I and II: Initial blastocyst type I and II

The use of human chorionic gonadotropin has been reported in all studies on induction of ovulation in cats previously stimulated for follicular development, although in a wide range of doses (Wildt et al., 1978; Platz et al. 1978; Dresser et al., 1988; Howard et al., 1992; Pope et al., 1993; Kanda et al., 1995; Pope et al., 1998; Tsutsui et al., 2000; Mattos et al. 2003). In this experiment, the dose of $100 \mathrm{IU}$ hCG, $4 \mathrm{~h}$ after pre-stimulation with eCG, was effective in promoting ovulation in all the animals used. Although being subjective, the recovery rate in these animals, that is, the number of embryos and oocytes recorded compared with the number of luteal bodies observed, was $66 \%$, which was very close to $74 \%$ reported by Tsutsui et al. (2000).

In the embryogenesis process, approximately five days after ovulation, the embryos enter the uterus mostly as a compact morula (Swanson et al., 1994). The best results in embryo transfer were observed when compact morulas were used (Swanson et al., 1994; Tsutsui et al., 2000). Thus, in the present study, the protocol for embryo recovery adopted was five to six days after ovulation induction. The technique described for uterine washing in embryo recovering proved efficient, since none of the donor queens became pregnant, even without receiving any aborticide treatment.

The present study may represent an important step for the preservation of neotropical felid species, because assisted reproduction technologies developed in domestic species have a real potential to be used in nondomestic species (Ballou, 1992; Pope et al., 1993; Swanson et al., 1996; Pope, 2000). The continuous pressure of illegal hunting and the progressive decrease in the habitats have led, according to the criteria by Mace \& Lande (1991), Tewes \& Everett (1986) and Tewes \& Schmidly (1987) to the inclusion of all the Brazilian wildcat species in the endangered species list. In the last ten years, conservation programs, starting from assisted reproduction of these felids, have increased mainly in Brazil, Mexico and the United States (Swanson \& Brown, 2004). Recent extremely encouraging practical results involving wild felids have been reported, for example, the birth of a Felis sylvestris lybica cub, resulting from an interspecific transfer gestated in a domestic queen (Pope, 2000). The development and adaptation of techniques for assisted reproduction can help maintain viable genetic variability for the survival of wild species that are threatened with extinction (Swanson et al., 1996; Ballou, 1992; Wildt et al., 1992; Wildt et al., 1993).

\section{CONCLUSION}

Results of the present study allow us to conclude that the protocol tested in this study was efficient to induce ovarian activity and ovulation. The embryo recovery rate was within the range normally reported in the literature and the technique uterine trans-horn washing was efficient in the recovering of embryos. The embryo transfer protocol tested was effective resulting in full-term pregnancy, within the patterns of duration and species' offspring number in $50 \%$ of the receptor animals.

\section{REFERENCES}

Ávila EC, Paula TAR, Coutinho ACR, Minami A \& Araújo AC (2003) Avaliação do ciclo estral de gatas domésticas (Felis catus) através de colpocitologia. In: XIII Simpósio de Iniciação Científica, Viçosa. Anais, UFV. 760p.

Ballou JD (1992) Potential contribution of cryopreserved germ plasma to the preservation of genetic diversity and conservation of endangered species in captivity. Cryobiology, 29:19-25.

Bowen RA (1977) Fertilization in vitro of feline ova by spermatozoa from the ducts deferens. Biology of Reproduction, $17: 144-147$.

Bowen RA, Olson PN, Olson JD \& Nett TM (1982) Concentration of reproductive hormones in canine serum throughout late anoestrus, proetrus and oestrus. Biology of Reproduction, 27:1196-1206. 
Byers AP, Barone MA, Donoghue M \& Wildt DE (1992) Mature domestic cat oocyte does not express a cortical granule-free domain. Biology of Reproduction, 47:709-715.

Christiansen IJ (1988) Reprodução no cão e no gato. São Paulo, Manole. 362p.

Cline EM, Jennings LL \& Sojka NJ (1980) Breeding laboratory cats during artificially induced oestrus. Laboratory Anima Science, 30:1003-1005.

Donoghue AM, Byers AP, Johnston LA, Armstrong DL \& Wildt DE (1996) Timing of ovulation after gonadotrophin induction and its importance to successful intrauterine insemination in tiger (Pantera tigris). Journal of Reproduction and Fertility, 107:53-58

Donoghue AM, Johnston LA, Munson L, Brown JL \& Wildt DE (1992) Influence of gonadotrophin treatment interval on follicular maturation, in vitro fertilization, circulating steroid concentrations, and subsequent luteal function in the domestic cat. Biology of Reproduction, 46:972-980.

Dresser BL, Gelwicks EJ, Wach KB \& Keeler GL (1988) First successful transfer of cryopreserved feline (Felis catus) embryos resulting in live offspring. Journal of Experimental Zoology, 246:180-186.

Goméz MC, Pope EC, Harris R, Mikota S \& Dresser BL (2003) Development of in vitro matured, in vitro fertilized domestic cat embryos following cryopreservation, culture and transfer. Theriogenology, 60:239-251.

Goodrowe KL, Howard JG, Schmidt PN \& Wildt DE (1989) Reproductive biology of the domestic cat with special reference to endocrinology, sperm function and in vitro fertilization. Journal of Reproduction and Fertility, 39:73-90.

Goodrowe KL, Wall RJ, O'brien SJ, Schmidt PMS \& Wildt DE (1988) Developmental competence of domestic cat follicular oocytes after fertilization in vitro. Biology of Reproduction, 39:355-372.

Greulich WW (1934) Artificially induced ovulation in the cat (Felis domestica). The Anatomical Record, 58:217-224.

Guimarães MABV( 2002) Biotecnologia aplicada aos animais silvestres: aspectos éticos e conservacionistas. Revista Brasileira Reprodução Animal, 26:58-61

Howard JG (1998) Assisted reproduction in non-domestic carnivores. In: Fowler ME (Ed.) Zoo and Wildlife medicine Philadelphia, WB Saunders. p.87-112.

Howard JG, Barone MA, Donoghue AM \& Wildt DE (1992) The effect of pre-ovulatory anaesthesia on ovulation in laparoscopically inseminated domestic cats. Journal of Reproduction and Fertility, 96:175-186

Jemmett JE \& Evans JM (1977) A survey of sexual behaviour and reproduction of female cats. Journal of Small Anima Practice, 18:31-37.

Jewgenow K \& Göritz F (1995) The recovery of preantral follicles from ovaries of domestic cats and their characterisation before and after culture. Animal Reproduction Science, 39:285-297.

Johnson LM \& Gay VL (1981) Luteinizing hormone in the cat. II. Mating induced secretion. Endocrinology, 109:247-252.

Johnston SD, Kustritz MVR \& Olson PNS (2001) The feline oestrous cycle. Canine and Feline. Theriogenology, 25:396 405 .

Johnston SD, Root MV \& Olson PNS (1996) Ovarian and testicular function in the domestic cat: clinical management of spontaneous reproductive disease. Animal Reproduction Science, 42:261-274.
Kanda M, Oikawa H, Nakao H \& Tsutsui T (1995) Early embryonic development in vitro and embryo transfer in the cat. Journal Veterinary Medicine Science, 57:641-646.

Karja NWK, Otoi T, Murakami M, Fahrundin M \& Suzuki T (2002) In vitro maturation, fertilization and development of domestic cat oocytes recovered from ovaries collected at three stages of the reproductive cycle. Theriogenology, 57:22892298.

Kitiyanant Y, Saikhun J \& Pavasuthipaisit K (2003) Somatic cell nuclear transfer in domestic oocytes treated with IGF-I for in vitro maturation. Theriogenology, 59:1775-1786.

Kraemer DC, Flow BL, Schrivier MD, Kinney GM \& Pennycook JW (1979) Embryo transfer in the non human primate, feline and canine. Theriogenology, 25:396-405.

Leibo SP \& Songsasen N (2002) Cryopreservation of gametes and embryos of non-domestic species. Theriogenology, 57:303-326.

Mace GM \& Lande R (1991) Assessing extinction threats: toward a revaluation of IUCN threatened species categories. Conservation Biology, 5:148-157.

Mattos MRF, Mattos LS \& Silva LDM (2003) Vaginal cytology in queens with estrous induced with equine chorionic gonadotrophin. Revista Portuguesa de Ciências Veterinárias, 98:135-138

Murakami M, Otoi T, Karja NWK, Ooka A \& Suzuki T (2002) Effects of serum-free culture media on in vitro development of domestic cat embryos following in vitro maturation and fertilization. Reproductive Domestic Animal, 37:352-356.

Platz CC, Wildt DE \& Seager SWJ (1978) Pregnancy in the domestic cat after artificial insemination with previously frozen spermatozoa. Journal of Reproduction and Fertility, 52:519527.

Pope CE (2000) Embryo technology in conservation efforts for endangered felids Theriogenology, 53:163-174.

Pope CE, Johnson CA, Mcrae MA, Keller GL \& Dresser BL (1998) Development of embryos produced by intracytoplasmic sperm injection of cat oocytes. Animal Reproduction Science, 53:221236.

Pope CE, Keller GL \& Dresser BL (1993) In vitro fertilization in domestic and non-domestic cats including sequences of early nuclear events, development in vitro, cryopreservation and successful intra- and interspecies embryo transfer. Journal of Reproduction and Fertility, 47:189-201.

Robertson I \& Nelson RE (1998) Certificação e identificação de embriões. In: Stringfellow DA \& Seidel SM (Eds.) Manual da Sociedade Internacional de Transferência de Embriões. $3^{\mathrm{a} e d .}$ Illinois, Sociedade Brasileira de Transferência de Embriões. p. 109-140.

Roth TL, Swanson WF \& Wildt DE (1994) Developmental competence of domestic cat embryos fertilized in vivo versus in vitro. Biology of Reproduction, 51:441-451.

Shille VM, Lundstrom KE \& Stanbenfeldt GH (1979) Follicular function in the domestic cat as determinate by estradiol-17ß concentrations in plasma: Relation to estrous behaviours and cornification of exfoliated vaginal epithelium. Biology of Reproduction, 21:953-963.

Skrzyszowska M, Katska L, Rynska B, Kania G, Smorag Z \& Pienkowski M (2002) In vitro developmental competence of domestic cat embryos after somatic cloning: a preliminary report. Theriogenology, 58:1615-1621.

Swanson WF \& Brown JL (2004) International training programs in reproductive sciences for conservation of Latin American felids. American Reproduction Science, 82:21-34. 
Swanson WF \& Godke RA (1994) Transcervical embryo transfer in the domestic cat. Laboratory Animal Science, 44:288-291.

Swanson WF, Horohov DW \& Godke RA (1995) Production of exogenous gonadotrophin-neutralizing immunoglobulins in cats after repeated eCG-hCG treatment and relevance for assisted reproduction in felids. Journal of Reproduction and Fertility, 105:35-41.

Swanson WF, Howard JG, Roth TL, Brown JL, Alvarado T, Burton M, Starnes D \& Wildt DE (1996) Responsiveness of ovaries to exogenous gonadotropins and laparoscopic insemination with frozen-thawed spermatozoa in ocelots (Felis pardalis). Journal of Reproduction and Fertility, 106:87-94.

Swanson WF, Roth TL \& Wildt DE (1994) In vivo embryogenesis, embryo migration and embryonic mortality in the domestic cat. Biology of Reproduction, 51:452-464.

Tewes ME \& Everett DD (1986) Status and distribution of the endangered ocelot and jaguarondi in Texas. In: Miller SD \& Everett DD (Eds.) Cats of the World: Biology, Conservation and Management. Washington DC, National Wildlife Federation. p. 147-158.

Tewes ME \& Schmidly DJ (1987) The Neotropical felids: jaguar, ocelot, margay, and jaguarundi. In: Novak M, Baker JA, Obbard ME \& Malloch B (Eds.) Wild Furbearer Management and Conservation in North America. Ontario, Ministry of Natural Resources. p.697-712.

Tsutsui T, Sakai Y, Matsui Y, Sato M, Yamane I, Murao I \& Stabenfeldt GH (1989) Induced ovulation in cats using porcine pituitary gland preparation during the non-breeding season. Japanese Journal Veterinary Science, 51:677-683.
Tsutsui T, Yamane I, Hattori I, Kurossawa N, Matsunaga H, Murao I, Kanda M \& Hori T (2000) Feline embryo transfer during the non-breeding season. Journal Veterinary Medicine Science, 62:1169-1175.

Verhage HG, Beamer NB \& Brenner RM (1976) Plasma levels of estradiol and progesterone in the cat during polyestrus, pregnancy and pseudopregnancy. Biology of Reproduction, 14:579-585.

Wildt DE \& Seager SWJ (1978) Ovarian response in the estral cat receiving varying doses of hCG. Hormone Research, 9:144150 .

Wildt DE, Monfort SL, Donoghue AM, Johnston LA \& Howard JG (1992) Embryogenesis in conservation biology-or how to make an endangered species embryo. Theriogenology, 37:161184.

Wildt DE, Seager SWJ \& Chakraborty PK (1980) Effect of copulatory stimuli on incidence of ovulation and on serum luteinizing hormone in the cat. Endocrinology, 107:1212-1217.

Wildt DE, Seal US \& Rall WF (1993) Genetic resource banks and reproductive technology for wildlife conservation. In: Cloudand JG \& Thorgaard GH (Eds.) Genetic Conservation of Salmonid Fishes. New York, Plenum Press. p.159-173.

Wood TC, Byers AP, Jenette BE \& Wildt DE (1995) Influence of protein and hormone supplementation on in vitro maturation and fertilization of domestic cat eggs. Journal of Reproduction and Fertility, 104:315-323. 